Diabetologia 10, 77-83 (1974)

(C) by Springer-Verlag 1974

\title{
Effect of Small Doses of Insulin in Vivo on the Proliferation and Cellularity of Adipose Tissue
}

\author{
L. Kazdová, P. Fábry and A. Vrána \\ Research Centre of Metabolism and Nutrition of the Institute for Clinical and Experimental Medicine, Prague, \\ Czechoslovakia
}

Received: May 15, 1973, and in revised form: October 18, 1973

\begin{abstract}
Summary. The effect of insulin in vivo on the proliferation and cellularity of epididymal adipose tissue of growing rats was investigated. Following the intraperitoneal administration of small amounts of insulin $(500 \mu \mathrm{U} /$ rat, twice a day), which did not influence the blood sugar level and food intake, it was found that repeated administration of insulin for $48-72 \mathrm{~h}$ leads in adipose tissue to an enhanced incorporation of ${ }^{14} \mathrm{C}$-2-thymidine into DNA and to an increase of the total amount of DNA and RNA in the fat body. The enhanced DNA synthesis in adipose tissue of insulin-treated rats was marked in nuclear DNA and absent in mitochondrial DNA. After
\end{abstract}

fractionation of adipose tissue by collagenase an enhanced DNA synthesis was found in the fraction of adipose and stromavascular cells. Morphological examination of adipose tissue of insulin-treated rats revealed cells in the phase of mitotic division and an increased ratio of fat cells of smaller size. Calculation of the number of cells in the epididymal fat body revealed that, after administration of insulin, the number of adipose and stromavascular cells increased.

Key words: Adipose tissue, insulin, fat cell size, fat cell number, DNA synthesis, mitosis.
The growth of rat adipose tissue by hyperplasia of adipocytes continues postnatally for at least 15 weeks [1]. This process can be stimulated by some factors, such as hyperphagia in the early postnatal period [2], refeeding [3] and resection of fat bodies [4]. The hyperplasia plays a part also in excessive growth of adipose tissue in some types of obesity [5-8]. The control of proliferation in adipose tissue has not been elucidated. However some experimental investigations suggest that insulin plays a role in this process. The participation of this hormone in the triggering of DNA synthesis has been observed both in vitro and in vivo in many tissues, e.g. the mammary gland [9], in liver [10], cartilage [11] or in muscle [12]. As far as adipose tissue is concerned, the findings on the influence of insulin on adipose tissue proliferation are equivocal. Salans found that the long-term administration of large amounts of insulin produced only hypertrophy of adipocytes [13]. On the other hand, Hausberger found that two weeks of insulin administration induced an actual increase in the number of adipose tissue cells [14]. Also, experiments on alloxan-diabetic rats showed that insulin was essential for maintenance of proliferation of stromal and fat cell precursors [15]. Evidence of the role of insulin in the regulation of adipose tissue proliferation is suggested also by findings that insulin enhances DNA synthesis in human adipose tissue in vitro [16] and stimulates mitotic activity of differentiated adipocytes in cultured brown fat cells [17].

The object of the present work was to assess whether insulin in vivo influenced the proliferation and cellularity of adipose tissue of growing rats.

The effect of insulin was investigated after intraperitoneal administration of small amounts of the hormone, which acutely stimulates the glycogen and lipid synthesis in epididymal adipose tissue without affecting the blood glucose level $[18,19]$ or food intake [20]. Under these experimental conditions counteractions from the organism, such as the inhibition of endogenous insulin secretion [21] or the enhanced secretion of other hormones [22-24], which may occur after insulin-induced hypoglycaemia, are eliminated.

The results indicate that repeated administration of small doses of insulin leads to enhanced DNA synthesis, mitotic activity and cellularity of adipose tissue. The preliminary results of this work were published earlier [25].

\section{Materials and Methods}

For all the experiments male rats, Wistar strain (Velaz breed), aged eight weeks and weighing 180$200 \mathrm{~g}$ were used. The animals were fed ad libitum a standard laboratory diet containing $25 \mathrm{cal} \%$ protein, $22 \mathrm{cal} \%$ fat and $53 \mathrm{cal} \%$ carbohydrate. All animals had free access to water throughout the experiments. Crystalline insulin (Spofa) was injected intraperitoneally twice daily for $1-6$ days in doses which are given below. Control animals received the same volume of saline. Animals were killed by decapitation at $20-22 \mathrm{~h}$ after the last injection.

The epididymal fat pads were removed, weighed and the parts distal to the major blood vessel were placed into the incubation medium to investigate DNA synthesis in vitro.

The advantage of the in vitro system, as compared to the in vivo system, is in the exposure of the tissue to a uniform and sufficient concentration of the precursor for a measured period of time. These conditions also eliminate possible differences in the distribution, degradation and reincorporation of the precursor into 
DNA [26, 27]. Adipose tissue was incubated in KrebsRinger bicarbonate buffer $\left(1 / 2 \mathrm{Ca}^{++1}\right) ; \mathrm{pH} 7.4$; gaseous phase $95 \% \quad \mathrm{O}_{2}+5 \% \quad \mathrm{CO}_{2}$; in a Dubnoff metabolic shaker at $37^{\circ} \mathrm{C}$. The incubation medium contained $0.9 \mathrm{mg} / \mathrm{ml}$ glucose and $2.5 \mathrm{mg} / \mathrm{ml}$ bovine serum albumin. As DNA precursor, $0.5 \mu \mathrm{C} / \mathrm{ml}$ of ${ }^{14} \mathrm{C}-2-$ thymidine (S.A. $46 \mathrm{mC} / \mathrm{mMol}$, ÚVVVR, Czechoslovakia) was added to the medium. Thymidine labelled thus - on a pyrimidine base of the molecule - is, according to some findings, more specific for the investigation of DNA synthesis than the frequently used methyl- ${ }^{3} \mathrm{H}$-thymidine, where the labelled tritium may be incorporated into lipids and proteins [28, 29]. This non-specific incorporation may be the source of erroneous conclusions on DNA synthesis in long-term experiments or with partial digestion of proteins by the action of strong alkali during DNA extraction using Schmidt-Thannhauser's method [30].

After three hours incubation the adipose tissue was analyzed for its nucleic acid content. As will be mentioned, in some experiments from adipose tissue after incubation with thymidine, fat and stromavascular cells were isolated by means of collagenase, as described by Rodbell [31]. In the experiment where the synthesis of nuclear and mitochondrial DNA was investigated, the nuclei and mitochondria were separated from the fat cell fraction by preparatory centrifuging [32].

DNA was extracted after delipidation [33] of tissue or cellular fractions, as described by Schneider [34]. The method was compared in some experiments with DNA extraction according to Schmidt-Thannhauser [35]. For this purpose the Fleck and Munro' modification [30] was used, where the contamination of extracted nucleic acids with peptides is reduced as compared with the original method of Schmidt-Thannhauser. The DNA concentration was measured either by the reaction with diphenylamine [34] or by ultraviolet absorbance at 265-290 m $\mu$. Calf-thymus DNA (Koch-Light, England) was used to construct a standard curve. Both methods of DNA estimation gave similar results.

The radioactivity in the extracted DNA was measured after dissolving in dioxane scintillation liquid (SLD 31, Tesla) in a scintillation spectrometer (ABAC, Intertechnique, France).

The amount of RNA in adipose tissue was determined by the orcinol reaction [34] and the protein content by Lowry's method [36].

The fat cell size was assessed by microscopic measurement of the diameter of fat cells prepared, as mentioned above, by Rodbell's method and fixed in $2.5 \%$ glutaraldehyde. In every animal, by means of an ocular micrometer, the diameter of 100 cells was measured. The number of fat cells in epididymal fat pads was estimated by dividing the total tissue lipid content - determined according to Folch [37] - by the average fat cell mass (mean fat cell volume $\mathrm{x}$ lipid density 0.91). The number of stromavascular cells was calculated from the whole DNA content in epididymal fat pads by subtracting the DNA content of the fat cells.

For determination of the mitotic activity adipose tissue was removed immediately after decapitation of the animals. Small portions of the tissue were fixed in a mixture of ethanol:acetic acid (3:1). After staining with aceto-orcein the ratio of cells undergoing mitosis was assessed in preparations prepared by squashing the tissue.

The results were evaluated statistically using Student's t-test.

\section{Results}

\section{Effect of Doses and the Time Course}

Table 1 presents the changes of DNA synthesis in relation to graded doses of insulin injected intraperitoneally twice daily for a period of $72 \mathrm{~h}$. Enhanced incorporation of ${ }^{14} \mathrm{C}-2$-thymidine is apparent even after as small doses as $200 \mu \mathrm{U} / \mathrm{rat}$ and it reached its maximum after $500 \mu \mathrm{U} /$ rat. Between doses of $500 \mu \mathrm{U}$ and $2 \mathrm{U}$ we did not find a further increase of DNA synthesis. A similar relation to the amount of injected insulin was observed for DNA content of adipose tissue.

Table 1. Effect of graded doses of insulin on incorporation of ${ }^{14} \mathrm{C}$-2-thymidine into adipose tissue $D N A$

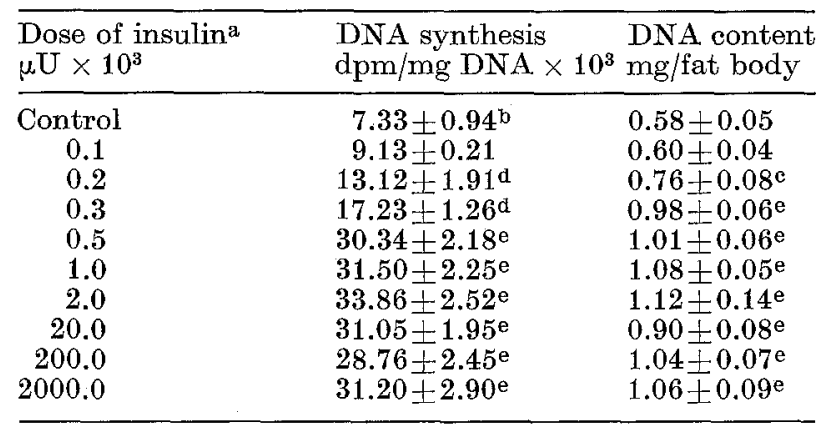

a Each dose of insulin was injected twice daily for three days.

${ }^{b}$ Average of $6-9$ rats per group \pm S.E.

c Difference as compared with control rats are statisti cally significant at $p<0.05$.

d $p<0.01$.

e $p<0.001$.

In subsequent experiments we investigated the time course of DNA synthesis and of the nucleic acid content. One to six hours after injection of insulin we did not find any changes in the investigated parameters. Fig. 1. presents the results of another experiment where we investigated DNA synthesis and the nucleic acid content $24-96 \mathrm{~h}$ after the beginning of insulin administration. It is apparent that the DNA synthesis was significantly increased after $24 \mathrm{~h}$ and reached maximum values after $48 \mathrm{~h}$. Seventy-two hours after insulin administration the thymidine incorporation 
fell, but even after two weeks administration the synthesis was still higher (though not significantly) by $27 \%$ as compared with control values. The administration of insulin also increased the total amount of DNA and RNA in the epididymal fat bodies (second part of Fig. 1). The increased nucleic acid content persisted also during subsequent time intervals.

Since adipose tissue contains large numbers of nonfat cells whose DNA synthesis is greater [38], we made experiments where we assessed the insulin-stimulated

INCORPORATION OF ${ }^{14} \mathrm{C}-2-$ THYMIDINE
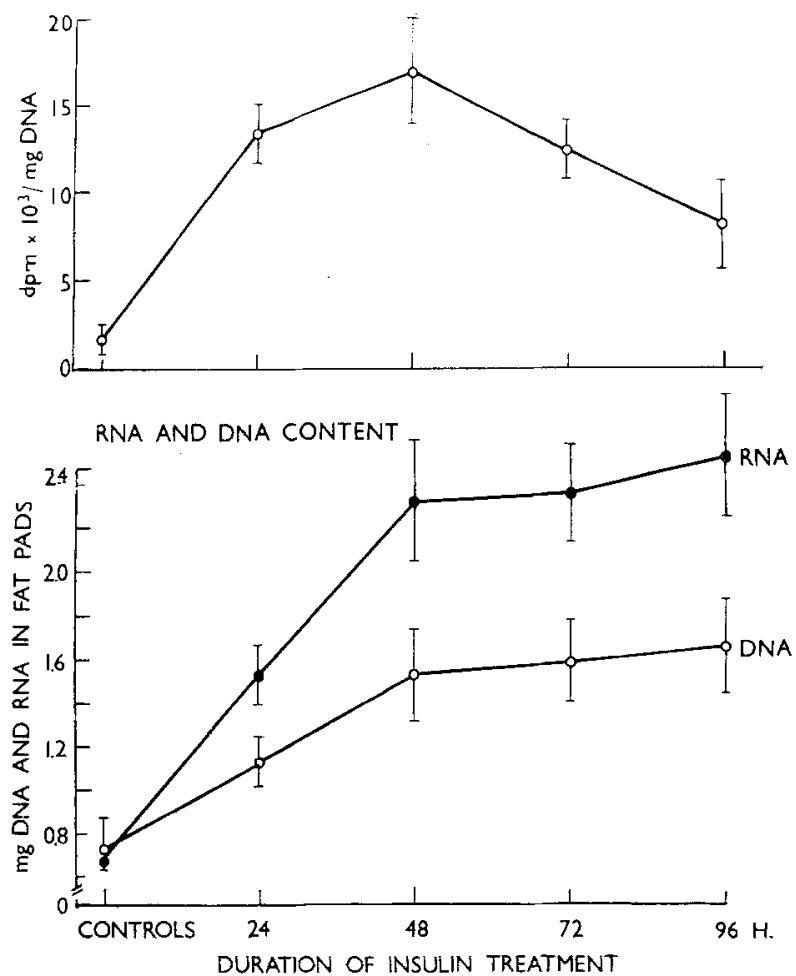

Fig. 1. Time course of DNA synthesis and nucleic acid content in epididymal fat pads of insulin treated rats $(500 \mu \mathrm{U} /$ rat twice daily). Each point represents averages \pm S.E.M. for $5-10$ animals. The $p$ values for the differences in DNA synthesis of control and insulin-treated rats are $<0.001$ for $24,48,72 \mathrm{~h}$ and $<0.01$ for $96 \mathrm{~h}$. The $p$ values for the differences in nucleic acid content are $<0.01$ for $24 \mathrm{~h}$ and $<0.001$ for 48,72 and $96 \mathrm{~h}$

DNA synthesis in the cellular pools of fat and stromavascular cells. In agreement with the findings of the other authors $[38,39]$, histological examination of individual cell fractions isolated by Rodbell's methods [31] revealed that absolute separation of adipocytes from stromavascular cells is impossible, despite repeated purification of the fat cell pool. Therefore the cellular constituents of the adipose tissue were divided after digestion with collagenase into fat cells, intermediary (containing both fat cells and stromavascular cells) and the stromavascular fraction, From Fig. 2, which illustrates the results of one of our representative experiments, it is apparent that insulin-stimulated DNA synthesis accurs in all investigated fractions of adipose tissue. In this experiment we also investigated the effect of insulin on DNA synthesis in the major blood vessel supplying the epididymal fat pad. Small portions of the vessel $(20 \mathrm{mg})$ were incubated with ${ }^{14} \mathrm{C}-2$-thymidine and after three hours incubation DNA was extracted. From the values presented in Fig. 2 it is apparent that insulin stimulated ${ }^{14} \mathrm{C}$-2-thymidine incorporation into DNA in the vessel to a small and statistically insignificant extent.

From the above results it may be concluded that, under the influence of insulin, enhanced DNA synthesis occurs in the fraction of fat cells as well as stromavascular cells. As regards vessels, we may conclude that DNA synthesis is not enhanced in the major blood vessels.

\section{Synthesis of Nuclear and Mitochondrial DNA}

Subsequent analyses were focussed on the problem whether synthesis and accumulation of DNA actually

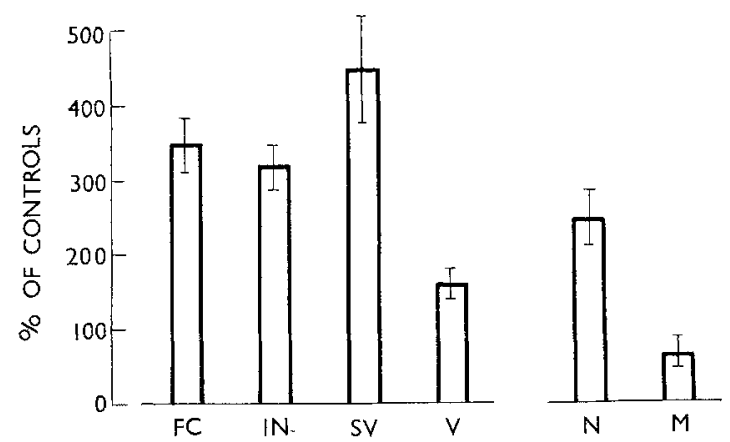

Fig. 2. Effect of insulin treatment ( $500 \mu \mathrm{U} /$ rat, twice daily for two days) on incorporation of ${ }^{14} \mathrm{C}$-2-thymidine into DNA of different fractions of adipose tissue. Fat cells (FC), intermediary (IN) and stromavascular (SV) fractions as well as nucleic (N) and mitochondria (M) of fat cells were isolated after incubation of adipose tissue with ${ }^{14} \mathrm{C}-2$ thymidine. (V)-incorporation of thymidine into DNA of incubated isolated vessel. Each point represents average \pm S.E. for $6-9$ animals. Specific activity (dpm/mg DNA) is expressed as percent of the control values. The $p$ values for the difference in DNA synthesis of the control and insulin-treated rats are $<0.001$ for $(\mathrm{FC})$, (IN), (SV) fraction and $<0.01$ for DNA isolated from nucle

reflect enhanced cell division. The possibility that enhanced thymidine incorporation is DNA synthesis for polyploidy seems unlikely as polyploid nuclei in adipose tissue are found only in older rats [39]. Also our preliminary experiments, where we examined the tissue histologically following its fixation in formaldehyde and after Feulgen staining, did not reveal any differences in the intensity of the dye content of nuclei. The occurrence of binucleated fat cells was equal in both our experimental groups and amounted to about $3 \%$. 
In subsequent experiments we investigated whether insulin stimulated the synthesis of extranuclear DNA. In recent years it has been demonstrated that about $2 \%$ of the total DNA content in cells is accounted for by mitochondrial DNA, which has a more rapid turnover than nuclear DNA and which is synthesized also in cells which do not undergo division $[40,41]$. From the values of ${ }^{14} \mathrm{C}$-2-thymidine incorporation into mitochondrial and nuclear DNA it is apparent (Fig. 2) that insulin stimulated, in our experimental procedure, only the synthesis of nuclear DNA.

\section{Morphology of Adipose Tissue}

The above results indicate that insulin-stimulated synthesis and accumulation of DNA in adipose tissue most probably reflect enhanced cell division. Evidence for this assumption is provided by the incidence of mitotic figures in the adipose tissue (Fig. 3) of insulintreated rats (in adipose tissue of control rats mitoses were recorded only rarely) as well as by data on changes
Table 2. Effect of insulin treatment on mean diameter and mass of fat cells and the fat and stromavascular cell number in epididymal fat pads

\begin{tabular}{lcc}
\hline & \multicolumn{2}{l}{ Insulin } \\
\cline { 2 - 3 } & 0 & $500 \mu \mathrm{U} / \mathrm{rat}^{\mathrm{b}}$ \\
\hline $\begin{array}{l}\text { Weight of animals }(\mathrm{g}) \\
\text { Weight of epididymal fat }\end{array}$ & $201 \pm 3.2^{\mathrm{a}}$ & $198 \pm 2.9$ \\
pads (g) & $1.966 \pm 770$ & $2.033 \pm \mathbf{4 1 5}$ \\
Lipid content in fat & $1.533 \pm 0.060$ & $1.585 \pm 0.032$ \\
pads (g) & $65.3 \pm 0.8$ & $60.7 \pm 0.6^{\mathrm{d}}$ \\
Fat cell diameter $(\mu)$ & & \\
Mass of the single fat cell & & \\
Fat cell number $\left(\times 10^{-6}\right)$ & $131.9 \pm 5.2$ & $105.5 \pm 3.0^{\mathrm{d}}$ \\
Stromavascular cell & $11.72 \pm 0.86$ & $15.08 \pm 0.51^{\mathrm{c}}$ \\
number $\left(\times 10^{6}\right)$ & $73.22 \pm 5.95$ & $138.77 \pm 5.47^{\mathrm{d}}$ \\
\hline
\end{tabular}

a Average of 4 and 7 rats per group \pm S.E.

b Insulin was injected twice daily in a dose $500 \mu \mathrm{U} /$ rat for three days.

c Difference as compared with control rats are statistically significant at $p<0.01$.

d At $p<0.001$.

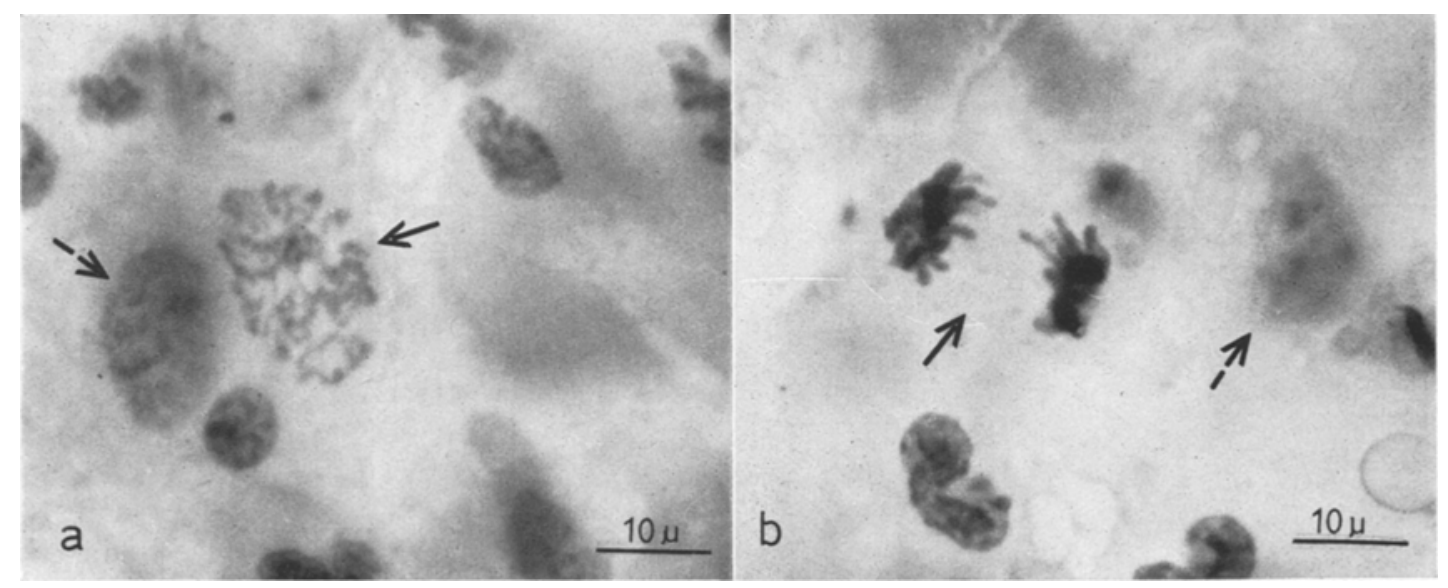

Fig. 3. Light micrograph of a squash preparation of adipose tissue from insulin treated rats (500 $\mu \mathrm{U} / \mathrm{rat}$, twice daily for $48 \mathrm{~h}$ ). Note cells in phases of mitosis (solid arrows) (a) the prophase nuclei, (b) anaphasetelophase nuclei. Nuclei of fat cells (broken arrows)

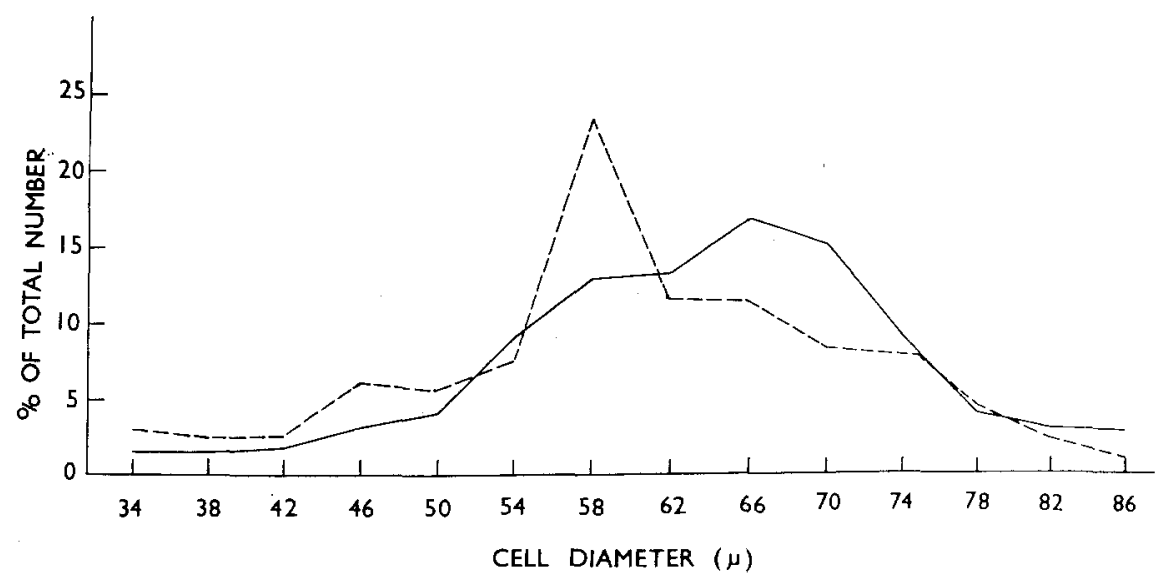

Fig. 4. Distribution curve of the fat cell size in control (- - ) and insulin ( $500 \mu \mathrm{U} / \mathrm{rat}$, twice daily for three days) treated rats (-........). Distribution curves represent diameters of fat cells from 5 and 6 animals per group 
in cell size and number. The distribution curve of the fat cell size (Fig. 4) indicates that in rats receiving insulin for $72 \mathrm{~h}$ the ratio of smaller adipocytes increased. Table 2 summarizes the results of the experiment where we assessed, in addition to the total DNA and lipid content, the size of fat cells in adipose tissue. From these values we calculated, according to Rakow [42] and Di Girolamo [43], the mass of single fat cells and the number of fat and stromavascular cells. From the values it is apparent that the total number of fat and stromavascular cells in the epididymal fat pads of the insulin-treated rats was increased.

\section{Discussion}

The present work confirms our previous findings on the stimulating effect of exogenous insulin on DNA synthesis [25]. It indicates also that the DNA synthesis is associated with adipose tissue cell proliferation, but is not accompanied by the formation of polyploid nuclei or binucleated cells. At the same time the mitochondrial DNA synthesis is not enhanced. As the response occurs after administration of small doses of insulin (which do not affect the blood glucose level and food intake) it may be assumed that the hormone directly stimulates the adipose tissue. This assumption is supported also by the fact that insulin stimulates DNA synthesis in incubated human adipose tissue [16] and enhances mitotic division in cultured brown fat cells [17].

Our experiments further show that a higher adipose tissue proliferation induced by insulin is accompanied by formation not only of stromavascular cells [15] but also of new fat cells. This is suggested by the increased number of adipocytes assessed by calculation and histological examination which revealed an increase in the number of smaller fat cells. This finding is in agreement with previous observations of Renold [44] and Hausberger $[14,45]$ that chronic administration of insulin induced an increase in small, apparently young, fat cells in adipose tissue. The result of our experiments, where we investigated the DNA synthesis in the fraction of fat and stromavascular cells, revealed that insulin stimulates DNA synthesis in all fractions including the adipocytes. With reference to the technical difficulties discussed above, it is impossible to determine whether DNA synthesis in the fat cell fraction is due to a greater proliferation of preadipocytes or possible contamination of the fraction with stromavascular cells. Some findings pertaining to the division of differentiated cells suggest the former of two possibilities. Investigations of various tissues revealed that processes of proliferation and differentation are not mutually exclusive; on the contrary, differentation of cells is associated with an enhanced proliferating activity [46, 47]. Also Pilgrim's recent findings [48] support the possibility that in the fat cell fraction of insulin-treated rats DNA synthesis may be enhanced as a result of a greater proliferation of partly differentiated fat cells. This author found in adipose tissue during the early postnatal period the highest proliferating activity in preadipocytes and not in non-differentiated mesenchymal cells. As preadipocytes may already contain small lipid inclusions $[49,50]$, they may pass into the fat cell fraction. In this connection Master's observation [17] is of interest. He showed that insulin in cultured interscapular adipose tissue did not enhanced mitotic division in fibroblasts, but did in well-differentiated fat cells.

The findings pertaining to the effect of insulin on the increase in the number of fat cells are not in agreement with the conclusions of Hollenberg [15] and Salans [13], as in their experiments exogenous insulin caused only hypertrophy of adipocytes. Although different results may be due to the application of different methods or different strains of rats [51], it must be emphasized that our experimental conditions differed from those used by the above authors. In both investigations the effect of exogenous insulin was studied after the long-term administration of large amounts of the hormone $(6 \mathrm{U} / \mathrm{rat}$ and $5 \mathrm{U} / 100 \mathrm{~g}$ body weight resp.). These doses lead to an increased food intake [20], which may affect the proliferation of body fat and hypertrophy of adipocytes. On the other hand, in our experiments the effect of insulin on the cellularity of adipose tissue was investigated after administration of small amounts of hormone. Under these conditions insulin causes acute stimulation of adipose tissue $[18,19]$, while the blood sugar level, food intake and body weight are not affected. The fact that the amounts used in our experiments led to a marked proliferation and increase of adipose and stromavascular cells, but not to an increase of lipids in the epididymal fat body, is of interest. The explanation of this phenomenon can be only speculative. It must be considered that the net increase of body fat usually depends in the first place on the energy balance of the whole animal, which under our experimental conditions was not affected.

The idea is attractive that insulin may be one of the factors which play a role in the regulation of adipose tissue proliferation. This idea is suggested by findings that under conditions associated with temporary hyperinsulinaemia, such as refeeding with a high carbohydrate diet [52], infrequent feeding [53], or hyperphagia in the early postnatal period [54], DNA synthesis and the number of fat cells in adipose tissue are enhanced $[2,3,55]$. Also in some types of experimental obesity, where excessive growth of adipose tissue is associated with hyperplasia $[7,8]$, increased plasma insulin levels were found $[56,57]$. On the other hand, changes in the proliferation and cellularity of adipose tissue were not found under conditions when the insulin level is not altered, e.g. during refeeding with a high-fat diet [58]. The important role of insulin in the maintenance of basal proliferating activity of adipose tissue is suggested also by findings of a reduced 
DNA synthesis during fasting [3] or in alloxan diabetic rats [38]. Before final conclusions on the role of insulin in adipose tissue hyperplasia can be drawn, however, more detailed information will required.

\section{References}

1. Hirsch, J., Han, P.W.: Cellularity of rat adipose tissue: Effects of growth, starvation and obesity. $J$. Lipid Res. 10, 77-82 (1969)

2. Knittle, J.L., Hirsch, J.: Effect of early nutrition on the development of rat epididymal fat pads: Cellularity and metabolism. J. clin. Invest. 47, 2091-2098 (1968)

3. Kazdová, L., Braun, T., Fábry, P.: Increased DNA synthesis in epididymal adipose tissue of rats refod after a single fast. Metabolism 16, 1174-1176 (1967)

4. Taylor, A. W., MeBean-Hopkins, K.: DNA content of regenerating epididymal fat pads. Growth 35, 341348 (1971)

5. Martinsson, A.: Hypertrophy and hyperplasia of human adipose tissue in obesity. Pol. Arch. Med. wewnet. 42, 481-486 (1969)

6. Gries, F.A., Daweke, H., Liebermeister, H.: Diabetes mellitus bei Fettsucht. Verh. dtsch. Ges. inn. Med. 76, $51-72(1970)$

7. Herberg, L., Gries, F.A., Hesse-Wortmann, C.: Effect of weight and cell size on hormonal induced lipolysis in New Zealand obese mice and American obese hyperglycemic mice. Diabetologia 6, 300-305 (1970)

8. Johnson, P.R., Zucker, L.M., Cruce, J.A.F., Hirsch, J.: Cellularity of adipose depots in the genetically obese Zucker rat. J. Lipid Res. 12, 706-714 (1971)

9. Turkington, R.W.: Hormone-induced synthesis of DNA by mammary gland in vitro. Endocrinology 82, $540-546(1968)$

10. Younger, L.R., King, J., Steiner, D.F.: Hepatic proliferative response to insulin in severe alloxan diabetes. Cancer Res. 26, 1408-1313 (1966)

11. Salmon, W.D., Jr., Du Vall, M.R., Thompson, E.Y.: Stimulation by insulin in vitro incorporation of $\left({ }^{35} \mathrm{~S}\right)$ sulphate and $\left({ }^{14} \mathrm{C}\right)$ leucine into protein polysaccharide complexes, $\left({ }^{3} \mathrm{H}\right)$ uridine into RNA and $\left({ }^{3} \mathrm{H}\right)$ thymidine into DNA of costal cartilage from hypophysectomized rats. Endocrinology 82, 493-499 (1968)

12. De la Haba, G., Cooper, G.W., Elting, V.: Hormonal requirements for myogenesis of striped muscle in vitro: Insulin and somatotropin. Proc. Soc. exp. Biol. (N. Y.) 56, 1719-1723 (1966)

13. Salans, L.B., Zarnowski, M.J., Segal, R.: Effect of insulin upon the cellular character of rat adipose tissue. J. Lipid Res. 13, 616-623 (1972)

14. Hausberger, F.X., Hausberger, B.C.: Composition of adipose tissue in several forms of obesity. Anat. Rec. 127, $305(1957)$

15. Hollenberg, C.H., Vost, A., Patten, R.L.: Regulation of adipose mass: control of fat cell development and lipid content. Recent Progr. Hormone Res., 26, 463$503(1970)$

16. Esanu, C., Murakawa, S., Bray, G.A., Raben, M.S.: DNA synthesis in human adipose tissue in vitro. I. Fffect of serum and hormones. J. clin. Endocr. 29, $1027-1032(1969)$

17. Masters, E.M.: Mitotic activity in cultured brown fat cells. Exp. Cell Res. 59, 334-336 (1970)

18. Rafaelsen, O.J.: Glycogen content of rat diaphragm after intraperitoneal injection of insulin and other hormones. Acta Physiol. scand. 61, 314-322 (1964)

19. Rafaelsen, O.J., Lauris, V., Renold, A.E.: Localized intraperitoneal action of insulin on rat diaphragm and epididymal adipose tissue in vivo. Diabetes 14, $19-26$ (1965)
20. Kumaresan, P., Turner, C.W.: Effect of graded levels of insulin on feed consumption in normal female rats. Proc. Soc. exp. Biol. (N.Y.) 120, 828-831 (1965)

21. Malaisse, W., Malaisse-Lagae, F.: Chronic effect of insulin and glucagon upon islet function. Diabetologia 5, $349-352(1962)$

22. Luft, R., Cerasi, E, Madison, L.L., Von Euler, U.S., Della Casa, L., Roovete, A.: Effect of a small decrease in blood-glucose on plasma-growth hormone and urinary excretion of catecholamines in man. Lancet 1966 VI, $254-256$

23. Ohneda, A., Aguilar-Parada, E., Eisentraut, A.M.: Control of pancreatic glucagon secretion by glucose. Diabetes 18, 1- 10 (1969)

24. Takebe, K., Kunit, H., Sawano, S., Horiuchi, Y., Mashimo, K.: Circadian rhythms of plasma growth hormone and cortisol after insulin. J. clin. Endocr. 12, $1630-1633(1969)$

25. Kazdová, L., Vrána, A.: Insulin and adipose tissue cellularity. Horm. Metab. Res. 2, $117-118$ (1970)

26. Brière, N., Isler, H.: Deoxyribonucleic acid labelling after tritiated thymidine injection. Canad. J. Physiol. Pharmacol. 44, 451-454 (1966)

27. Baugnet-Mahieu, L., Goutier, R.: Reutilization of labelled-thymidine and -iododeoxyuridine for nuclear and mitochondrial DNA synthesis in regenerating rat liver. Arch. Int. Physiol. Biochim. 80, 319-330 (1972)

28. Bryant, B.J.: The incorporation of tritium from thymidine into proteins of the mouse. J. Cell Biol. 29, $29-36(1966)$

29. Kazdová, L., Fábry, P., Vrána, A.: Comparison of the specificity of ${ }^{14} \mathrm{C}$ - and ${ }^{3} \mathrm{H}$-thymidine as a precursor of deoxyribonucleic acid. Physiol. bohemoslov. 21, 89$90(1972)$

30. Fleck, A., Munro, H.N.: The precision of the ultraviolet absorption measurements in the SchmidtThannhauser procedure for nucleic acid estimation. Biochim. biophys. Acta (Amst.) 55, 571-583 (1962)

31. Rodbell, M. : Metabolism of isolated fat cells. I. Effects of hormones on glucose metabolism and lipolysis. J. biol. Chem. 239, 375-380 (1964)

32. Angel, A., Sheldon, H.: Adipose cell organelles: isolation morphology and possible relation to intracellular lipid transport. Ann. N.Y. Acad. Sci. 131, 157-176 (1965)

33. Steele, W.J., Okamura, N., Busch, H.: Prevention of loss of DNA, RNA and protein into lipid solvents. Biochim. biophys. Acta (Amst.) 87, 490-492 (1964)

34. Schneider, W.C.: Determination of nucleic acid in tissues by pentose analysis. In: Methods in Enzymology (eds. Colowick, S.P., Kaplan, N.O., Vol. 3, pp. 680-684. New York: Academic Press 1957

35. Schmidt, G., Thannhauser, S.J.: A method for the determination of DNA, RNA and phosphoproteins in animal tissues. J. biol. Chem. 161, 83-98 (1945)

36. Lowry, O.H., Rosenbrough, N.J., Farr, A.L., Randall, R.J. : Protein measurement with the Folin phenol reagent. J. biol. Chem. 193, 265-275 (1951)

37. Folch, J., Lees, M., Sloane-Stanley, G.H.: A simple method for the isolation and purification of total lipids from animal tissues. J. biol. Chem. 226, 497-509 (1957)

38. Hollenberg, O.H., Vost, A.: Regulation of DNA synthesis in fat cells and stromal elements from rat adipose tissue. J. clin. Invest. 47, 2485-2498 (1968)

39. Mohr, W., Beneke, G.: Age depence of nuclear content of rat adipose cells. Experientia 24, 1052-1053 (1968)

40. Rabinowitz, M.: Extranuclear DNA. Bull. Soc. Chim. biol. 50, 311 - 348 (1968)

41. Wierzbicki, R., Bartkowiak, J.: Kwas dezoksyrybonukleinowy mitochondriach. Postepy Biochem. 9, 577$586(1966)$ 
42. Rakow, L., Beneke, G., Mohr, W., Brauchle, I.: Untersuchungen über die Zellvermehrung im weißen Fettgewebe der genetisch adipösen Maus (C 57 BL/6J ob/ob). Beitr. Path. 143, 301-311 (1971)

43. Di Girolamo, M., Skinner, N.S., Hanley, H.G., Sachs, R.G.: Relationship of adipose tissue blood flow to fat cell size and number. Amer. J. Physiol. 220, 932 - 937 (1971)

44. Renold, A.E., Marble, A., Fawcett, D.W.: Action of insulin on deposition of glycogen and storage of fat in adipose tissue. Endoerinology 46, 55-66 (1950)

45. Hausberger, F. X., Hausberger, B.C.: Effect of insulin and cortisone on weight gain, protein and fat content of rats. Amer. J. Physiol. 193, 455-460 (1958)

46. Redman, R.S., Sreebny, L.M.: Proliferative behavior of differentiating cells in the developing rat parotid gland. J. Cell Biol. 46, 81--87 (1970)

47. Mazhuga, P.M., Zhitnikov, A.Y., Kharchuk, K.N.: Differentiation and reproduction of cells in chondrogenesis. Anat. Anz. 126, 172-181 (1970)

48. Pilgrim, Ch.: DNA synthesis and differentiation in developing adipose tissue. Develop. Biol. 26, 69-76 (1971)

49. Napolitano, L.M.: Observations on the fine structure of adipose cells. Ann. N.Y. Acad. Sci. 131, 34-42 (1965)

50. Vodovar, N., Desnoyers, F., Flanzy, J.: Depot adipeux mésentérique du porcelet étude morphologique. Ann. Biol. anim. 12, 243-262 (1972)

51. Kazdová, L., Fábry, P., Vrána, A. : Postnatal development of cellularity of adipose tissue in different strains of rats. Physiol. bohemoslov (in press)
52. Szepesi, B., Berdanier, C.D.: Time course of the starve-refed response in rats; the possible role of insulin. J. Nutr. 101, 1563-1574 (1971)

53. Vrána, A., Fábry, P., Braun, T.: Periodic hyperinsulinaemia in meal-fed rats. Physiol. bohemoslov. 18, 498-499 (1966)

54. Asplund, K.: Effect of postnatal feeding on the functional maturation of pancreatic islet $B$-cells of neonatal rats. Diabetologia 8, 153-159 (1972)

55. Braun, T., Kazdová, L., Fábry, P., Lojda, Z., Hromádková, V.: "Meal eating" and refeeding after a single fast as a stimulus for increasing the number of fat cells in abdominal adipose tissue of rats. Metabolism 17, 825 (1968)

56. Chlouverakis, C., Dade, F.F., Batt, R.A.L.: Glucose tolerance and time sequence of adiposity, hyperinsulinaemia and hyperglycemia in obese hyperglycemic mice. Metab. clin. Exp. 19, 687-693 (1970)

57. Zucker, L.M., Antoniades, H.N.: Insulin and fattening in the genetically obese hyperlipemic rat "Fatty". Fed. Proc. 29, 379 (1970) (Abstr.)

58. Kazdová, L., Fábry, P., Braun, T.: Composition of diet and response of adipose tissue to refeeding. Physiol. bohemoslov. 17, 569 (1968)

Dr. L. Kazdová

Institute for Clinical and Experimental Medicine

Budějovická 800

14622 Prague 4

Czechoslovakia 